\title{
Serum Visfatin Levels in Patients with Anorexia Nervosa and Bulimia Nervosa
}

\author{
I. DOSTÁLOVÁ ${ }^{1}$, D. SEDLÁČKOVÁ ${ }^{2}$, H. PAPEŽOVÁ ${ }^{3}$, J. NEDVÍDKOVÁ ${ }^{2}$ M. HALUZÍK \\ ${ }^{1}$ Third Department of Medicine, First Faculty of Medicine and General University Hospital, Prague, \\ ${ }^{2}$ Institute of Endocrinology, Laboratory of Clinical and Experimental Neuroendocrinology, Prague, \\ ${ }^{3}$ Department of Psychiatry, First Faculty of Medicine and General University Hospital, Prague, \\ Czech Republic
}

Received September 8, 2008

Accepted November 18, 2008

On-line December 17, 2008

\begin{abstract}
Summary
Visfatin is an adipose tissue-derived hormone shown to correlate with visceral fat mass in patients with obesity. Its possible role in patients with different types of eating disorders is unknown. We measured fasting serum levels of visfatin and leptin and surrogate measures of insulin sensitivity in 10 untreated patients with anorexia nervosa (AN), 10 untreated patients with bulimia nervosa (BN) and 20 age-matched healthy women (C) to study the possible role of visfatin in these disorders. Patients with AN had severely decreased body mass index (BMI) and body fat content. BMI of BN group did not significantly differ from that of $\mathrm{C}$ group, whereas body fat content of BN group was significantly lower compared to $\mathrm{C}$ and higher compared to AN group, respectively. Serum glucose levels did not significantly differ among the groups studied, whereas serum insulin and leptin levels and HOMA index were significantly decreased in AN group relative to both $C$ and $B N$ group. In contrast, serum visfatin levels in both patients with $\mathrm{AN}$ and $\mathrm{BN}$ did not differ from those of $\mathrm{C}$ group. We conclude that circulating visfatin levels are not affected by the presence of chronic malnutrition in AN or binge/purge eating behavior in $\mathrm{BN}$.
\end{abstract}

\section{Key words}

Anorexia nervosa $\bullet$ Bulimia nervosa $\bullet$ Visfatin $\bullet$ Adipose tissue

\section{Corresponding author}

M. Haluzik, Third Department of Medicine, First Faculty of Medicine, U Nemocnice 1, 12800 Prague 2, Czech Republic. E-mail: mhalu@If1.cuni.cz
Visfatin is a novel adipokine originally described to be produced predominantly by visceral adipose tissue and to exert insulin-mimetic and adipogenic effects (Fukuhara et al. 2005). Contrary to the initial report (Fukuhara et al. 2005), further studies concerning the association of visfatin with obesity and diabetes have brought up controversial results (Haider et al. 2006, Jian et al. 2006, Lopez-Bermejo et al. 2006, Chen et al. 2007, Dogru et al. 2007, Sandeep et al. 2007, Varma et al. 2007). Furthermore, the predominant contribution of visceral over subcutaneous fat depot to serum visfatin in humans has been questioned by some studies (Berndt et al. 2007). The effect of weight loss on circulating concentrations of visfatin in obese patients has been numerously documented, but the results are rather conflicting (Haider et al. 2006, Krzyzanowska et al. 2006, Manco et al. 2007).

It is currently unclear whether visfatin represents a marker of fat mass and/or function or whether it may also exert a direct regulatory role in energy metabolism. To our best knowledge, the changes and possible role of visfatin in the pathophysiology of eating disorders have not been described so far. The restrictive form of anorexia nervosa (AN) represents an extreme example of psychosomatic-based malnutrition induced by chronically decreased food intake caused by inappropriate fear of obesity and distorted body image (DSM-IV 1994). As a consequence of this abnormal self-body attitude, the severe weight and fat loss occurs in these patients.

PHYSIOLOGICAL RESEARCH • ISSN 0862-8408 (print) • ISSN 1802-9973 (online)

(c) 2009 Institute of Physiology v.v.i., Academy of Sciences of the Czech Republic, Prague, Czech Republic

Fax+420 241062 164, e-mail: physres@biomed.cas.cz, www.biomed.cas.cz/physiolres 
Bulimia nervosa $(\mathrm{BN})$ is an eating disorder characterized, in contrast to AN, by normal or even slightly higher body mass index (BMI). Patients with BN suffer from repeated episodes of binge eating combined with inappropriate compensatory behavior to prevent weight gain such as self-induced vomiting, misuse of laxatives, diuretics, fasting, and excessive exercise (DSM-IV 1994). The presence of either $\mathrm{AN}$ or $\mathrm{BN}$ affects body weight and fat mass and consequently energy metabolism differently, but both eating disorders are associated with alterations of various hormones, including adipokines (Baranowska et al. 2001, Monteleone et al. 2002, Housová et al. 2005, Dostálová et al. 2006, Kř́žová et al. 2007, Haluzíková et al. 2008). These endocrine abnormalities might contribute to the pathophysiology of $\mathrm{AN}$ and $\mathrm{BN}$ (Dostálová et al. 2006, 2007, Modan-Moses et al. 2007, Doležalová et al. 2007).

We measured circulating concentrations of visfatin in 10 previously untreated female patients with restrictive subtype of $\mathrm{AN}, 10$ previously untreated female patients with $\mathrm{BN}$ and 20 age-matched healthy women to study its possible role in the pathophysiology of eating disorders. The characteristic of the study subjects is shown in Table 1.

The diagnosis of eating disorders was based on the diagnostic system (DSM-IV 1994). A clinical evaluation of the patients was performed by an experienced psychiatrist. The structured Clinical Interview MINI 5.0 was used for diagnostic assessment of patients. Patients were hospitalized on the Department of Psychiatry throughout the study. None of the studied subjects suffered from diabetes mellitus, thyroid disorder, and/or acute infectious disorder. All patients with AN had amenorrhea, whereas all patients with $\mathrm{BN}$ and healthy women were examined in the follicular phase of the menstrual cycle. Body weight of studied patients remained stable for at least three months prior the study. Written informed consent was provided by all participants before being enrolled in the study. The study was approved by the Human Ethical Review Committee, Institute of Endocrinology, Prague, Czech Republic, and was performed in accordance with the guidelines proposed in the Declaration of Helsinki.

All subjects were measured and weighed. Body fat content was estimated by bioimpedance analysis (Bodystat 1500, Bodystat Ltd., UK). Blood samples for visfatin evaluation were withdrawn between 7 and $8 \mathrm{~h}$ a.m. after $12 \mathrm{~h}$ of overnight fasting into tubes with aprotinin (500 U/liter). The serum was separated by
Table 1. Anthropometric, biochemical and hormonal characteristics of the studied subjects.

\begin{tabular}{lccc}
\hline & $\begin{array}{c}\text { Controls } \\
(\mathbf{n}=\mathbf{2 0})\end{array}$ & $\begin{array}{c}\text { AN } \\
(\mathbf{n}=\mathbf{1 0})\end{array}$ & $\begin{array}{c}\text { BN } \\
(\mathbf{n}=\mathbf{1 0})\end{array}$ \\
\hline $\begin{array}{l}\text { Age (years) } \\
\left.\text { BMI (kg/m }{ }^{2}\right)\end{array}$ & $22.6 \pm 0.45$ & $23.2 \pm 1.21$ & $21.2 \pm 0.85$ \\
Body fat & $23.7 \pm 1.34$ & $6.3 \pm 1.1 *^{*^{+}}$ & $13.8 \pm 1.73^{*}$ \\
content (\%) & & & \\
$\begin{array}{l}\text { Fasting insulin } \\
\text { (mIU/l) }\end{array}$ & $6.9 \pm 0.93$ & $2.2 \pm 0.29^{*}$ & $4.6 \pm 0.18$ \\
$\begin{array}{l}\text { Fasting } \\
\text { glucose } \\
\text { (mmol/l) }\end{array}$ & $4.7 \pm 0.12$ & $4.2 \pm 0.12$ & $4.2 \pm 0.08$ \\
$\begin{array}{l}\text { HOMA-R } \\
\text { Fasting visfatin } \\
\text { (ng/ml) }\end{array}$ & $44.0 \pm 6.27$ & $37.9 \pm 6.52$ & $39.8 \pm 2.90$ \\
$\begin{array}{l}\text { Fasting leptin } \\
\text { (ng/ml) }\end{array}$ & $5.6 \pm 0.64$ & $1.7 \pm 0.34^{*+}$ & $5.0 \pm 0.76$ \\
\hline
\end{tabular}

Values are expressed as mean \pm S.E.M.; $A N=$ anorexia nervosa; $\mathrm{BN}=$ bulimia nervosa; $\mathrm{BMI}=$ body mass index; HOMA-R = homeostasis model assessment of insulin resistance. ${ }^{*} p<0.05$ vs. C group; ${ }^{+} \mathrm{p}<0.05$ vs. BN group.

centrifugation and stored at $-80{ }^{\circ} \mathrm{C}$ until being assayed. Serum visfatin concentrations were measured by a commercial EIA kit (Phoenix Pharmaceuticals, Inc., CA, USA). The sensitivity was $1.8 \mathrm{ng} / \mathrm{ml}$, and the intra- and interassay variability was $5 \%$ and $14 \%$, respectively. Serum insulin concentrations were measured by commercial RIA kit (Cis Bio International, Gif-surYvette, France). Sensitivity was $2.0 \mu \mathrm{IU} / \mathrm{ml}$, and the intra- and interassay variability was 4.2 and $8.8 \%$, respectively. Serum glucose concentrations were measured in the Department of Biochemistry of General University Hospital by standard laboratory methods. Homeostasis model assessment (HOMA-R) index was calculated as previously described (Matthews et al. 1985) using the following formula: fasting serum insulin $(\mathrm{mIU} / \mathrm{l}) \mathrm{x}$ fasting serum glucose $(\mathrm{mmol} / \mathrm{l}) / 22.5$. The statistical analysis was performed on SigmaStat Software (Jandel Scientific, San Rafael, CA). The results are expressed as means \pm S.E.M. The groups were compared by one-way ANOVA on ranks. Differences between groups were evaluated using unpaired t-test and MannWhitney rank sum test as appropriate.

The main results of the study are summarized in Table 1. Patients with AN were extremely malnourished 
as evidenced by severely decreased BMI, percent of body fat and reduced serum leptin levels. BMI of BN group did not significantly differ from that of $\mathrm{C}$ group, whereas percent body fat of $\mathrm{BN}$ group was significantly lower and higher as compared to $\mathrm{C}$ and $\mathrm{AN}$ group, respectively. Fasting serum visfatin levels in either AN or BN group were not significantly different as compared to control group. Fasting serum glucose levels did not significantly differ among the groups studied, whereas fasting serum insulin and leptin levels were significantly decreased in patients with AN relative to both $\mathrm{C}$ and BN group. Serum insulin and leptin levels in $\mathrm{BN}$ group tended to be lower relative to $\mathrm{C}$ and higher relative to $\mathrm{AN}$ group, respectively, but these differences did not reach statistical significance. HOMA index values paralleled serum insulin levels, being markedly decreased in AN group, whereas no significant difference between $\mathrm{BN}$ and $\mathrm{C}$ group was found (Table 1).

The reduction of BMI significantly correlated with the changes of circulating visfatin levels after weight loss in some (Haider et al. 2006, Choi et al. 2007), but not in all previous studies (Krzyzanowska et al. 2006). However, all these studies were performed in obese patients undergoing bariatric surgery (Haider et al. 2006, Krzyzanowska et al. 2006, Garcia-Fuentez et al. 2007, Manco et al. 2007) or low-caloric diet combined with exercise training program (Choi et al. 2007). The groups of patients as well as the conditions of these studies are thus absolutely incomparable with chronic malnutrition of our patients with AN. Here we show that circulating levels of visfatin are not primarily related to the specific eating disorder. Furthermore, unchanged visfatin levels in patients with $\mathrm{AN}$ and $\mathrm{BN}$ do not support the thesis that visceral fat mass is a major determinant of this hormone in patients with these eating disorders (Zamboni et al. 1997). An alternative explanation could be that circulating levels of visfatin may not accurately reflect its production and/or function in peripheral tissues, including adipose tissue. We and others have previously shown that circulating levels of adipokines do not necessarily mirror its tissue levels (Hotamisligil and Spiegelman 1994, Dostálová et al. 2006, Doležalová et al. 2007). Thus, we can not exclude the possibility that, although circulating levels of visfatin are unchanged, local visfatin effects (e.g., glucose uptake by adipocytes) within the adipose tissue might be altered in patients with eating disorders. Another possible explanation of unaltered visfatin levels in patients with AN could lie in the differences in its clearance in patients with $\mathrm{AN}$ (Fukuhara et al. 2005, Berndt et al. 2007).

In summary, our data show that circulating visfatin levels are not affected either by the presence of chronic malnutrition in patients with anorexia nervosa or binge/purge eating behavior in patients with bulimia nervosa. Further investigation is needed to clarify the possible role of visfatin in eating disorders or its metabolic complications.

\section{Conflict of Interest}

There is no conflict of interest.

\section{Acknowledgements}

This study was supported by IGA MHCR no. NR9158-3, MZO 0064165 and MSM0021620814.

\section{References}

BARANOWSKA B, WOLINSKA-WITORT E, WASILEWSKA-DZIUBINSKA E, ROGUSKI K, CHMIELOWSKA M: Plasma leptin, neuropeptide Y (NPY) and galanin concentrations in bulimia nervosa and in anorexia nervosa. Neuro Endocrinol Lett 22: 356-358, 2001.

BERNDT J, KLOTING N, KRALISCH S, KOVACS P, FASSHAUER M, SCHON MR, STUMVOLL M, BLUHER M: Plasma visfatin concentrations and fat depot-specific mRNA expression in humans. Diabetes 54: 29112916, 2007.

CHEN CC, LI TC, LI CI, LIU CS, LIN WY, WU MT, LAI MM, LIN CC: The relationship between visfatin levels and anthropometric and metabolic parameters: association with cholesterol levels in women. Metabolism 56: 12161220, 2007.

CHOI KM, KIM JH, CHO GJ, BAIK SH, PARK HS, KIM SM: Effect of exercise training on plasma visfatin and eotaxin levels. Eur J Endocrinol 157: 437-442, 2007.

DSM-IV: Diagnostic and Statistical Manual of Mental Disorders. 4th ed. American Psychiatric Association, Washington, DC, 1994. 
DOGRU T, SONMEZ A, TASCI I, BOZOGLU E, YILMAZ MI, GENC H, ERDEM G, GOK M, BINGOL N, KILIC S, OZGURTAS T, BINGOL S: Plasma visfatin levels in patients with newly diagnosed and untreated type 2 diabetes mellitus and impaired glucose tolerance. Diabetes Res Clin Practice 76: 24-29, 2007.

DOLEŽALOVÁ R, LACINOVÁ Z, DOLINKOVÁ M, KLEIBLOVÁ P, HALUZÍKOVÁ D, HOUSA D, PAPEŽOVÁ H, HALUZÍK M: Changes of endocrine function of adipose tissue in anorexia nervosa: comparison of circulating levels versus subcutaneous mRNA expression. Clin Endocrinol 67: 674-678, 2007.

DOSTÁLOVÁ I, KUNEŠOVÁ M, DUŠKOVÁ J, PAPEŽOVÁ H, NEDVÍDKOVÁ J: Adipose tissue resistin levels in patients with anorexia nervosa. Nutrition 22: 977-983, 2006.

DOSTÁLOVÁ I, SMITKA K, PAPEŽOVÁ H, KVASNIČKOVÁ H, NEDVÍDKOVÁ J: Increased insulin sensitivity in patients with anorexia nervosa: the role of adipocytokines. Physiol Res 56: 587-594, 2007.

FUKUHARA A, MATSUDA M, NISHIZAWA M, SEGAWA K, TANAKA M, KISHIMOTO K, MATSUKI Y, MURAKAMI M, ICHISAKA T, MURAKAMI H, WATANABE E, TAKAGI T, AKIYOSHI M, OHTSUBO T, KIHARA S, YAMASHITA S, MAKISHIMA M, FUNAHASHI T, YAMANAKA S, HIRAMATSU R, MATSUZAWA Y, SHIMOMURA I: Visfatin: a protein secreted by visceral fat that mimics the effects of insulin. Science 307: 426-430, 2005.

GARCIA-FUENTES E, GARCIA-ALMEIDA JM, GARCIA-ARNES J, GARCIA-SERRANO S, RIVAS-MARIN J, GALLEGO-PERALES JL, ROJO-MARTÍNEZ G, GARRIDO-SÁNCHEZ L, BERMUDEZ-SILVA FJ, RODRÍGUEZ DE FONSECA F, SORIGUER F: Plasma visfatin concentrations in severely obese subjects are increased after intestinal bypass. Obesity (Silver Spring) 15: 2391-2395, 2007.

HAIDER DG, SCHINDLER K, SCHALLER G, PRAGER G, WOLZT M, LUDVIK B: Increased plasma visfatin concentrations in morbidly obese subjects are reduced after gastric banding. $J$ Clin Endocrinol Metab 91: 1578-1581, 2006.

HALUZÍKOVÁ D, DOSTÁLOVÁ I, KAVALKOVÁ P, ROUBÍČEK T, MRÁZ M, PAPEŽOVÁ H, HALUZÍK M: Serum concentrations of adipocyte fatty acid binding protein in patients with anorexia nervosa. Physiol Res $\mathbf{5 8}$ : 577-581, 2009.

HOTAMISLIGIL GS, SPIEGELMAN BM: Tumor necrosis factor alpha: a key component of the obesity-diabetes link. Diabetes 43: 1271-1278, 1994.

HOUSOVÁ J, ANDERLOVÁ K, KŘİŽOVÁ J, HALUZÍKOVÁ D, KŘEMEN J, KUMSTYROVÁ T, PAPEŽOVÁ H, HALUZÍK M: Serum adiponectin and resistin concentrations in patients with restrictive and binge/purge form of anorexia nervosa and bulimia nervosa. J Clin Endocrinol Metab 90: 1366-1370, 2005.

JIAN WX, LUO TH, GU YY, ZHANG HL, ZHENG S, DAI M, HAN JF, ZHAO Y, LI G, LUO M: The visfatin gene is associated with glucose and lipid metabolism in a Chinese population. Diabet Med 23: 967-973, 2006.

KŘIZŽOVÁ J, DOLINKOVÁ M, LACINOVÁ Z, SULEK S, DOLEŽALOVÁ R, HOUSOVÁ J, KRAJÍČKOVÁ J, HALUZÍKOVÁ D, BOŠANSKÁ L, PAPEŽOVÁ H, HALUZÍK M: Adiponectin and resistin gene polymorphisms in patients with anorexia nervosa and obesity and its influence on metabolic phenotype. Physiol Res 57: 539-546, 2008.

KRZYZANOWSKA K, MITTERMAYER F, KRUGLUGER W, KOPP HP, SCHERNTHANER G: Increase in visfatin after weight loss induced by gastroplastic surgery. Obesity (Silver Spring) 14: 1886-1889, 2006.

LOPEZ-BERMEJO A, CHICO-JULIA B, FERNANDEZ-BALSELLS M, RECASENS M, ESTEVE E, CASAMITJANA R, RICART W, FERNANDEZ-REAL JM: Serum visfatin increases with progressive betacell deterioration. Diabetes 55: 2871-2875, 2006.

MANCO M, FERNANDEZ-REAL JM, EQUITANI F, VENDRELL J, VALERA MORA ME, NANNI G, TONDOLO V, CALVANI M, RICART W, CASTAGNETO M, MINGRONE G: Effect of massive weight loss on inflammatory adipocytokines and the innate immune system in morbidly obese women. $J$ Clin Endocrinol Metab 92: 483-490, 2007.

MATTHEWS DR, HOSKER JP, RUDENSKI AS, NAYLOR BA, TREACHER DF, TURNER RC: Homeostasis model assessment: insulin resistance and beta-cell function from fasting plasma glucose and insulin concentrations in man. Diabetologia 28: 412-419, 1985. 
MODAN-MOSES D, STEIN D, PARIENTE C, YAROSLAVSKY A, RAM A, FAIGIN M, LOEWENTHAL R, YISSACHAR E, HEMI R, KANETY H: Modulation of adiponectin and leptin during refeeding of female anorexia nervosa patients. J Clin Endocrinol Metab 92: 1843-1847, 2007.

MONTELEONE P, MARTIADIS V, COLURCIO B, MAJ M: Leptin secretion is related to chronicity and severity of the illness in bulimia nervosa. Psychosom Med 64: 874-879, 2002.

SANDEEP S, VELMURUGAN K, DEEPA R, MOHAN V: Serum visfatin in relation to visceral fat, obesity, and type 2 diabetes mellitus in Asian Indians. Metabolism 56: 565-570, 2007.

VARMA V, YAO-BORENGASSER A, RASOULI N, BODLES AM, PHANAVANH B, LEE MJ, STARKS T, KERN LM, SPENCER HJ 3RD, MCGEHEE RE JR, FRIED SK, KERN PA: Human visfatin expression: relationship to insulin sensitivity, intramyocellular lipids, and inflammation. J Clin Endocrinol Metab 92: 666-672, 2007.

ZAMBONI M, ARMELLINI F, TURCATO E, TODISCO P, GALLAGHER D, DALLE GRAVE R, HEYMSFIELD S, BOSELLO O: Body fat distribution before and after weight gain in anorexia nervosa. Int $J$ Obes Relat Metab Disord 21: 33-36, 1997. 